\title{
Erratum to: Thermal Elastic Mechanics Problems of Concrete Rectangular Thin Plate
}

\section{Erratum to:}

X. Cheng, Thermal Elastic Mechanics

Problems of Concrete Rectangular Thin Plate, Springer Tracts in Civil Engineering, https://doi.org/10.1007/978-981-10-4472-4

In the original version of the book, the sales restriction text "Not for sale outside the Mainland of China (Not for sale in Hong Kong SAR, Macau SAR, and Taiwan, and all countries, except the Mainland of China)." has been now updated as "The printed edition is not for sale in China Mainland. Customers from China Mainland please order the print book from: Science Press, Beijing, China" in the Copyright page of Frontmatter. 